\title{
Knowledge and attitude towards antimicrobial self medication usage: a cross sectional study among medical and nursing students
}

\author{
Ritu Bala, Harminder Singh*, Kamlpreet Kaur, Girish P, Kamlesh Kohli
}

Department of Pharmacology, GGS Medical College, Faridkot151203, Punjab, India

Received: 22 May 2013

Accepted: 8 June 2013

\section{*Correspondence to:}

Dr. Harminder Singh,

Email:

dr_harminderchahal@rediffmail .com

(C) 2013 Bala R et al. This is an open-access article distributed under the terms of the Creative Commons Attribution License, which permits unrestricted use, distribution, and reproduction in any medium, provided the original work is properly cited.

\begin{abstract}
Background: Antimicrobial drug resistance is a fast mounting universal crisis. Many factors like self medication, inappropriate use and unregulated sale of medicines and self medication have been attributed to this problem. The objective was to determine extend and causes of antimicrobial self medication and to compare the knowledge attitude of senior and junior medical/nursing students.

Methods: We conducted a cross-sectional study on randomly selected 410 students from Baba Farid University of Health Sciences Faridkot, Punjab. A total sample of 220 medical students were enrolled from GGS Medical College, Faridkot ( $1^{\text {st }}$ year students 50 and 170 above $1^{\text {st }}$ year senior medical students ) and 190 nursing students were enrolled from University College of Nursing, Faridkot.

Results: prevalence of antimicrobial self medication came out to be around 74\%. The most common cause for seeking antimicrobial (self therapy) was upper respiratory tract infection. A statistical significant knowledge/attitude gap was found between senior and fresher medical/nursing students.

Conclusions: High prevalence of antimicrobial self medication among medical/nursing students is a matter of concern and it should be discouraged at appropriate level to safeguard students from preventable adversary exposure.
\end{abstract}

Keywords: Self medication, Antimicrobial resistance, Medical students

\section{INTRODUCTION}

Antimicrobial drug resistance is a fast mounting universal crisis. Many factors like inappropriate use of antibiotics, not following use of antibiotics by prescribing physician, unregulated sale of medicines and self medication have been accredited to the advancement of resistance to several antimicrobials. ${ }^{1,2}$ Other factors like lack or ignorance of microbiology services, using antibiotics for non bacterial infections like self remitted viral illness, have all led to overuse of antibiotics. $^{3,4}$

Among the factors described above antimicrobial self medication is important one which is further intensified by using leftover drugs from similar previous prescription or drugs obtained from known persons and easy accessibility of antimicrobial drugs at local pharmacy stores. The literature on self-medication with antimicrobial drugs in the developed world is limited.
Several studies indicate significant use of household leftovers drugs, a pharmacy, or from other sources., Furthermore, a substantial body of data has demonstrated common troubles in knowledge, attitudes, beliefs and behaviors among consumers which influence the antibiotic usage. 7,8

Apart from general consumer/public or patients, medical health care professionals are major determinant in this regard so their own knowledge in depth is very much necessary for use of rational antimicrobial therapy and their ability to spread the right message in community as a whole. A doctor or medical graduate student only after having undergone vigorous working out in pharmacology, human physiology, pathology and other related medical subjects becomes skilled enough to assess the benefits and hazards of the situation and then prescribe a appropriate antimicrobial medication. Therefore, drug prescription has been kept only for competent, medical graduates. 9,10 . 
It has been observed that medical students in developing country like us where physician/patients ratio is very less start antimicrobial self medication, prescribing medicines to each other and recommend to other people much earlier than they graduate from medical college. So it is very much needed to assess their ability or knowledge, attitude to discourage these practices. To know their skill regarding antimicrobial usages can be evaluated by means of so-called knowledge, attitudes surveys. These type of extensive survey however, to the best of our knowledge, have been rarely reported.

Being a future pillar of health care providing system medical student's skill, knowledge in this regard is decisive but there is a paucity of studies and literature which can assess the antimicrobial self-medication knowledge of medical students. The Medical students are exposed to lots of knowledge about diseases and drugs so they are naturally different from the general population. We therefore considered it necessary to discover this issue of antimicrobial self medication in medical and nursing students in order to address in terms of what proportion of antimicrobial self medication is prevalent, why they do it and what is their attitude towards this.

With above said concern we designed this study to obtained two important objectives i) To determine extend and causes of antimicrobial self medication ii) To compare the knowledge and attitude of senior and junior medical students with span of times.

\section{METHODS}

We conducted a cross-sectional study on selected 410 students from Baba Farid University of Health Sciences Faridkot, Punjab. A total sample of 220 medical students were enrolled from GGS Medical College, Faridkot ( $1^{\text {st }}$ year students 50 and 170 above $1^{\text {st }}$ year senior medical students ) and 190 nursing students were enrolled from University College of Nursing, Faridkot.

\section{Study Design and Population}

A cross-sectional survey using a validated selfadministered questionnaire was conducted from January to March 2013 among medical and nursing students. Prior written consent was taken from participating students, before starting this study. 410 students sample size was calculated with the help of confidence interval at $95 \%$ and precision 5\% sample size with over correction. Among 410 students, 105 students denied that they were not practicing Antimicrobial self medication, so over all percentage of Antimicrobial self medication prevalence came out around $74 \%$. A questionnaire was designed by reviewing relevant literatures and questionnaires previously used in similar studies. ${ }^{11}$

The questionnaires were pre-tested by administering them to 15 respondents who were not part of the sample population in order to determine the reliability of the questionnaire. The questionnaire comprised of two sections. In section first, question regarding demographic characteristics were asked. The second section had questions assessing the respondent's knowledge of antibiotic usage and infectious diseases.

Eight statements addressing attitude towards antibiotic usage were included (Table 1) in second section, modified and simplified five-point Likert scale was used for scoring. To simplify the analysis, we replaced "Strongly agree" and "strongly disagree" with simple Yes or No. Each correct answer awarded with one mark and wrong with zero mark. The minimum and maximum score was 0 and 8 respectively. At the end, we had three groups; group A (140 Nursing Students), Group B (50 $1^{\text {st }}$ year MBBS Medical Students) and group C (115 above $1^{\text {st }}$ year MBBS Students).

Table 1: Eight statements addressing attitudes toward antibiotic usage and scoring.

\begin{tabular}{|llll|}
\hline No & $\begin{array}{l}\text { Knowledge /Attitude } \\
\text { questionnaires }\end{array}$ & Yes & No \\
\hline 1 & $\begin{array}{l}\text { When I get a cold, I will take } \\
\text { antibiotics to help me get better } \\
\text { more quickly. }\end{array}$ & 0 & 1 \\
\hline 2 & $\begin{array}{l}\text { I normally stop taking antibiotics } \\
\text { when I start feeling better. }\end{array}$ & 0 & 1 \\
\hline 3 & $\begin{array}{l}\text { I normally will look at the expiry } \\
\text { date of antibiotics before taking } \\
\text { it. }\end{array}$ & 1 & 0 \\
\hline 4 & $\begin{array}{l}\text { If my family member is sick, I } \\
\text { usually will give my antibiotics } \\
\text { to them. }\end{array}$ & 0 & 1 \\
\hline 5 & $\begin{array}{l}\text { Common cold is caused by } \\
\text { bacteria }\end{array}$ & 0 & 1 \\
\hline 6 & $\begin{array}{l}\text { Antibiotic can alter the normal } \\
\text { GIT bacterial floras }\end{array}$ & 1 & 0 \\
\hline 7 & $\begin{array}{l}\text { If you get minor side effects with } \\
\text { antibiotics you can stop it }\end{array}$ & 0 & 1 \\
\hline 8 & $\begin{array}{l}\text { Use of antibiotics can reduces } \\
\text { the body own immunity }\end{array}$ & 0 & 1 \\
\hline & \begin{tabular}{l} 
Und \\
\hline
\end{tabular} & & \\
\hline
\end{tabular}

A reasonable scoring system was used to assess the level of knowledge based on the answers provided. The total knowledge score was categorized into three levels indicated by poor (0-3), moderate (4-6) and good (6-8). We compare the score of knowledge of antimicrobial self medication in three different groups described above.

\section{Statistical Analysis}

Demographic data tabulated and percentage proportion calculated appropriately. Descriptive data regarding attitude knowledge score in three different groups was analyzed by one way ANOVA and Turkey HSD Test for Post-ANOVA Pair-Wise Comparisons. In all statistical 
analyses, a p-value of $<0.05$ was considered to be statistically significant.

\section{RESULTS}

A total of 410 medical and nursing students enrolled in our survey out of which 305 students completed the questionnaires, 105 students denied that they have not taken any antimicrobial as self medication; prevalence came out to be around 74\% (Table 2). Out of total 305 students there were 140 nursing students (group-A), 50 medical 1st year (group-B) and 115 medical above 1st year (group-C). On analyzing the data we found maximum reason for self antimicrobial administration was previous prescription/ experience of medical/ nursing students Figure 3 . The most self medicated antimicrobial reported was penicillin group which was followed by macrolides group Figure 1. The most common cause for seeking antimicrobial (self therapy) was upper respiratory tract infection Figure 2. Analysis of knowledge attitude scoring of antimicrobial self therapy and their comparison in different groups were done by one way ANOVA and Turkey HSD Test for Post-ANOVA PairWise Comparisons and the finding was that group A versus group B was non-significant that means there is no appreciable knowledge difference was noted in these two groups. The comparison of Group A and B with Group C was highly significant (Table 3 ).

Table 2: Demographic characteristics of students participated.

\begin{tabular}{|c|c|c|}
\hline Characteristics & $\begin{array}{l}\text { Frequency } \\
(n=410)\end{array}$ & Percentage \\
\hline \multicolumn{3}{|l|}{ Respondent's sex } \\
\hline Male & $\begin{array}{l}105 \text { (8nuring+97 } \\
\text { Medical) }\end{array}$ & 25.61 \\
\hline Female & $\begin{array}{l}305(182 \\
\text { Nursing+ } 123 \\
\text { Medical })\end{array}$ & 74.39 \\
\hline \multicolumn{3}{|l|}{ Age in years } \\
\hline $17-19$ & 192 & 46.83 \\
\hline $19-21$ & 123 & 30 \\
\hline $21-23$ & 64 & 15.61 \\
\hline$>23$ & 31 & 07.56 \\
\hline \multicolumn{3}{|l|}{ Comparable groups } \\
\hline $\begin{array}{l}\text { Group A (Nursing } \\
\text { Students) }\end{array}$ & 190 & 46.34 \\
\hline $\begin{array}{l}\text { Group B ( } 1^{\text {st }} \text { year } \\
\text { Medical Students) }\end{array}$ & 50 & 12.20 \\
\hline $\begin{array}{l}\text { Group C (above } \\
1^{\text {st }} \text { year Medical } \\
\text { Students) }\end{array}$ & 170 & 41.46 \\
\hline
\end{tabular}

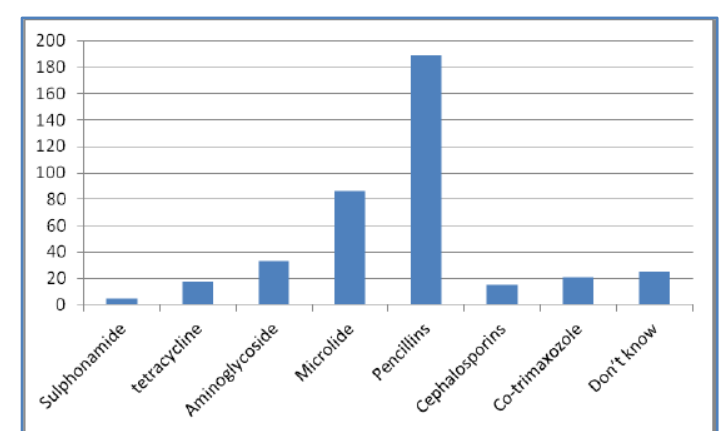

Figure 1: Reported common antimicrobial agents used as self medications.

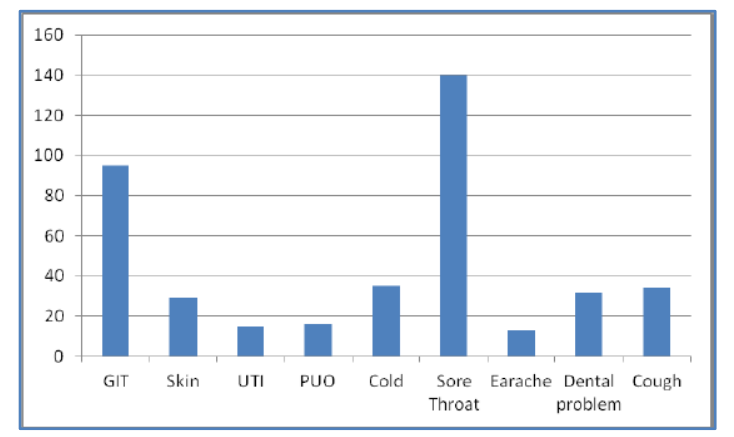

Figure 2: Reported symptoms for self antimicrobial medications.

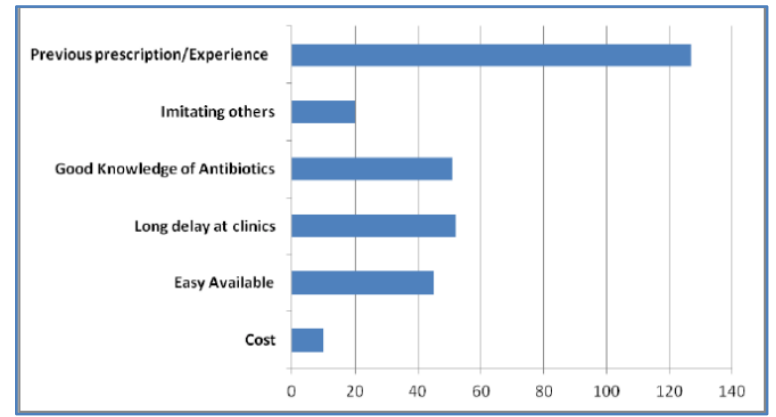

Figure 3: Reported reasons for self antimicrobial medications.

Table 3: Comparison of different group with help of one way ANOVA and Turkey HSD test for postANOVA pair-wise comparisons.

\begin{tabular}{|ll|}
\hline Vs & Group A \\
\hline Group A Vs Group B & Non significant \\
\hline Group A Vs Group C & Significant with $\mathrm{p}<.01$ \\
\hline Group B Vs Group C & Significant with $\mathrm{p}<.01$ \\
\hline
\end{tabular}

Note: Group A (140 Nursing Students), Group B (50 $1^{\text {st }}$ year MBBS Medical Students) and group C (115 above $1^{\text {st }}$ year MBBS Students). 


\section{DISCUSSION}

A high prevalence of antimicrobial self medication was noted $(74 \%)$, which was quite a high as compared to $16.6 \%$ in general population by Kim et al. ${ }^{11}$ Inappropriate Antimicrobial self-medication is a cause for worry because it may perhaps contribute to the extend of antimicrobial drug resistance. Self-treatment has so many shortcoming like ineffective antimicrobial selection, inappropriate dosage which may add-on resistant organisms that are complicated to get rid of so the secondary cumulative effects is drug interactions, masked diagnoses, and superinfection.

In general, the senior medical student secured good antimicrobial knowledge score and they felt that medical knowledge was making them more cautious about selfmedication .Many of them correctly supposed selfmedication as time-saving and economical, doing away with long delay at clinics for minor illness and self medication providing rapid, simple and suitable relief. These observation are comparable to those stated by the WHO that self-medication afford a cheaper and suitable alternative for treating common minor illnesses. ${ }^{12}$

Length of waiting time for medical consultation has been identified as one of the predictive factors for selfmedication by Martins et al. but in our study it was the previous experience of students that drove them towards self medication. ${ }^{13}$

A major proportion of students used antibiotics to alleviate and cure primarily viral upper respiratory tract infections and common cold/cough, where it was not specified. The false impression and uncertainty regarding the indications of antibiotics use, whether bacterial or viral infections seen in our study are evidenced in other reports too. ${ }^{14}$

We noted in our study that, sore throat and cough/cold being the most common cause for using self antimicrobial therapy. This finding was in concordance with studies done by James $\mathrm{H}$ et al which reported the same finding from other part of the world. ${ }^{15}$

First-year medical/nursing students were learner and they were exposed to lots of medical information regarding antimicrobial drug usage but having a very limited applied medical knowledge as shown by low mean attitude/knowledge score by First-year medical/nursing students in our study. They were at a risk of mislaid selfassurance and ignorance that may perhaps lead to inappropriate antimicrobial self-medication and exposed to all the risks associated with this. ${ }^{16}$

The useful assertion found in this study was that most of the students practiced reading drug labels for composition and expiry dates. It was also found that in $2^{\text {nd }}$ year students most common source of information was pharmacology which is taught to them in $2^{\text {nd }}$ year in comparison to $1^{\text {st }}$ year medical/nursing students where most common source of information was previous experience or family, friends and media etc.

\section{CONCLUSION}

The study identified important knowledge and attitude gaps in 1st year medical and nursing students but the gap narrowed up as the students attains specific knowledge about antimicrobial information in depth. Senior medical students, showed appropriate antimicrobial self medication as compared to juniors or fresher but still high prevalence is a matter of concern and it should be discouraged at appropriate level to safeguard students from preventable adversary exposure.

Funding: None

Conflict of interest: None declared

Ethical approval: No required

\section{REFERENCE}

1. Varghese RT, Das R. Antimicrobial drug resistance in India, Possible causes. Asian Stud Med J 2010;1:151-54.

2. Aleykutty NA, Jayakar B, Suresh P, Leena PN, Mathews SM. Effect of regulations on the appropriate use of antibiotics. Int J Pharma Bio Sci 2011;2:32-5.

3. Global Antibiotic Resistance Partnership-India (GARP-India). Situation analysis- Antibiotic Use and Resistance in India. Global Antibiotic Resistance Partnership-India National Working Group, March-2011. Available at http://www.cddep.org/sites/cddep.org/files/publicati on_files/India-report-web.pdf. (Accessed March 2013. 9-12).

4. Thomas JK, Forrest A, Bhavnani SM, Hyatt JM, Cheng A, Ballow $\mathrm{CH}$, et al. Pharmacodynamic evaluation of factors associated with the development of bacterial resistance in acutely ill patients during therapy. Antimicrob Agents Chemother 1998;42:521-27.

5. Richman PB, Garra G, Eskin B, Nashed AH, Cody R. Oral antibiotic use without consulting a physician: a survey of ED patients. Am J Emerg Med 2001;19:57-60.

6. Vanden Eng J, Marcus R, Hadler JL, Imhoff B, Vugia DJ, Cieslak PR,et al. Consumer attitudes and use of antimicrobial drugs. Emerg Infect Dis 2003;9:1128-35.

7. McNulty CAM, Boyle P, Nichols T, Clappison P and Davey J. Don't wear me out - the public's knowledge of and attitudes to antibiotic use. J Antimicrob Chemother 2007;59:727-38.

8. Hawkings NJ, Butler CC, Wood F. Antibiotics in the community: A typology of user behaviours. Patient Educ Couns 2008;73:146-52.

9. Han WH, Maxwell SR. Are medical students adequately trained to prescribe at the point of 
graduation? Views of first year foundation doctors. Scott Med J 2006;51:27-32.

10. Ibia E, Sheridan M, Schwartz R. Knowledge of the principles of judicious antibiotic use for upper respiratory infections: a survey of senior medical students. South Med J 2005;98:889-95.

11. Lim KK, Teh CC.A Cross Sectional Study of Public Knowledge and Attitude towards Antibiotics in Putrajaya, Malaysia. South Med Rev 2012;5:26-33.

12. World Health Organization: Report of the WHO Expert Committee on National Drug Policies 1995. http://www.who.int/medicines/ library/dap/whodap-95-9/who-dap-95.9.shtml.

13. Martins AP, Miranda AC, Mendes Z, Soares MA, Ferreira P, Nogueira A. Self-medication in a
Portuguese urban population: a prevalence study. Pharmacoepidemiol Drug Saf 2002;11:409-14.

14. McKee MD, Mills L, Mainous AG. Antibiotic use for the treatment of upper respiratory infections in a diverse common community. J. Fam. Pract 1999;48:993-96.

15. James H, Handu SS, Al Khaja KAJ, Otoom S, Sequeira RP. Evaluation of the knowledge, attitude and practice of self-medication among first-year medical students. Med. Princ. Pract 2006;15:270-75.

16. Hughes CM, McElnay JC, Fleming GF. Benefit and risks of self medication. Drug Saf 2001;24:1027-37.

doi:10.5455/2319-2003.ijbcp20130816

Cite this article as: Bala R, Singh $\mathrm{H}$, Kaur K, P

Girish, Kohli K. Knowledge and attitude towards antimicrobial self medication usage: a cross sectional study among medical and nursing students. Int $\mathbf{J}$ Basic Clin Pharmacol 2013;2:428-32. 